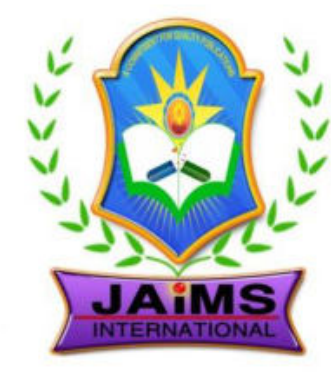

ISSN 2456-3110

Vol $5 \cdot$ Issue 1

Jan-Feb 2020

Journal of

Ayurveda and Integrated Medical Sciences

www.jaims.in

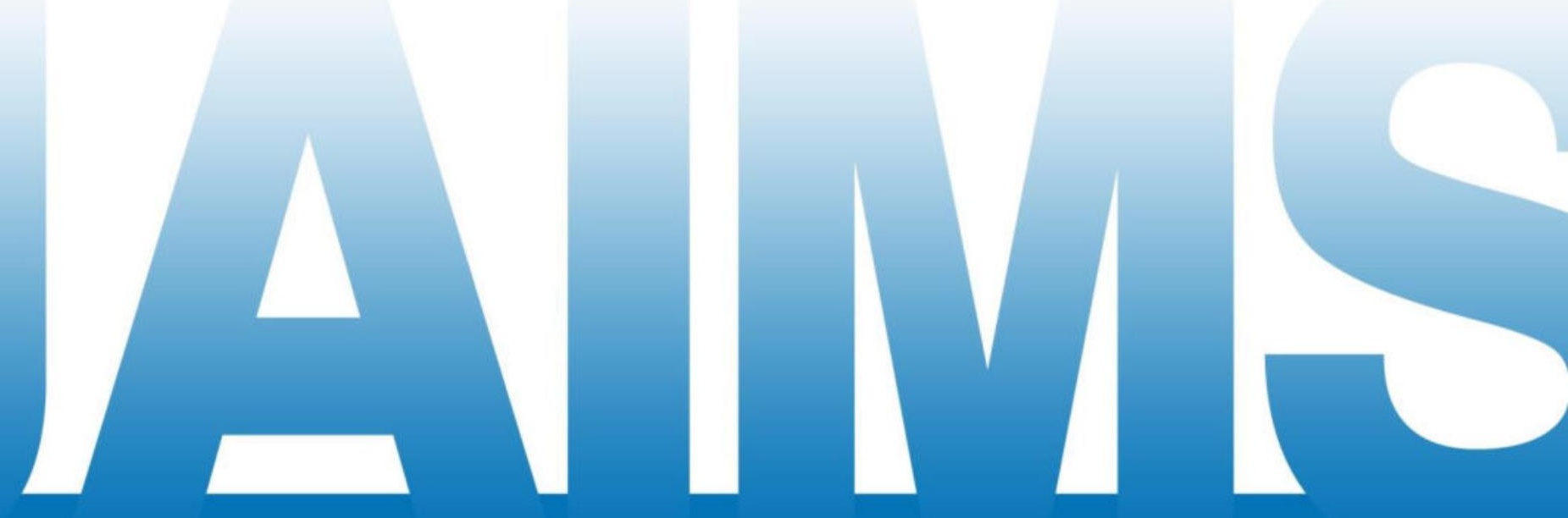

An International Journal for Researches in Ayurveda and Allied Sciences

\title{
Charaka
}




\section{Effect of Ayurvedic preparation on stages of labor - A Clinical Study}

\section{Dr. Priyanka}

Associate Professor, Dept. of Stri Roga and Prasuti Tantra, Chaudhary Devi Lal College of Ayurveda, Yamuna Nagar, Haryana, INDIA.

\section{A B STRACT}

\begin{abstract}
The process of giving birth to young ones is becoming complicated day by day. Different serious conditions were faced by females during the phenomenon of labor. The present clinical trial is a small but an effective effort to facile the complicated process of labor. It aims to reduce the intensity of pain with duration of the labour, to decrease the frequency of caesarean section and application of forceps at the time of delivery. To facilitate the phenomenon of labor (Sukh-Prasava) Aacharya Charaka indicates the use of Anuvaasana basti and picchu of taila medicated of madhura gan dravyas during ninth month of pregnancy. In this study tila taila murchit by madhura gana dravyas mixed with kwatha of four self assumed (kalpit dravyas) named Sukh-Prasava taila is used for soothing the phenomenon of labor. The 30 patients (Primigravida) were selected randomly, which were given Anuvaasana basti fortnightly and Picchu daily from the beginning of $9^{\text {th }}$ month till delivery with SukhPrasava taila. All routine laboratory investigations were also assessed. The patients treated with SukhPrasava taila had shown better results by successfully decreasing the standard mean duration of all the three stages of labour with intensity of pain.
\end{abstract}

Key words: Sukh-Prasava Taila, Picchu, Anuvasana Basti, Labor.

\section{INTRODUCTION}

In Ayurveda there is detailed description about how to live a quality and disease free daily life under heading Dincharya. ${ }^{[1]}$ The fact which is known to all is that, the segment of pregnancy and the phase of giving birth to young ones are the most problematical, critical and complex time of a woman's life. This critical stage starts from the very commencement of conceiving or when fertility occurs. During this significant stage each

\section{Address for correspondence:}

\section{Dr. Priyanka}

Associate Professor, Dept. of Stri Roga and Prasuti Tantra,

Chaudhary Devi Lal College of Ayurveda, Yamuna Nagar,

Haryana, INDIA.

E-mail: drvana88@gmail.com

Submission Date: 09/01/2020

Accepted Date: 14/02/2020

\begin{tabular}{|l|l|}
\hline & \multicolumn{2}{c|}{ Access this article online } \\
\hline Quick Response Code & Website: www.jaims.in \\
\hline
\end{tabular}

women undergoes a progression of emotional, mental and physical changes which persist all the way through pregnancy. Acharya Charak described "Garbhini Paricharya" in detail in which there is explanation of Ahara (diet), Vihara (life style) and Vichara (thought process) is mentioned which were to be followed by pregnant woman during pregnancy so that she will be able to deliver a child with good health with ease. ${ }^{[2]}$ In Shushrut Samhita Acharya Sushrut also illustrate the procedure of Prasava (delivery) and state that as a mature fruit naturally isolate from the stalk itself on the right course of time, in the same way Garbha (foetus) in its suitable time, also separate from its Nadinibandha (Umblical chord) and progress for Prasava. ${ }^{[3]}$ In classical text of Ayurveda, the accurate duration of Prasava (normal delivery) is not visibly mentioned but the adverse effects and their methods of management were talked about under heading vilambita prasava. ${ }^{[4]}$ For Sukha Prasava i.e. uncomplicated and normal delivery Acharya Charaka has mentioned the use of Anuvaasana Basti and Pichu of oil medicated with 
Madhura Gana Dravyas from the beginning of ninth month of pregnancy. ${ }^{[5]}$

The phase of pregnancy is very crucial phase and a correlation is made by Acharya Charak in perspective of a pregnant lady. Acharya Charak correlate a pregnant lady with a oil filled vessel and its minor fluctuation can result in spillage of oil. It can be explained as that a slight deviation in Aahara and Vihara of a pregnant lady may worsen or imbalance the Doshas and can cause adverse effects Garbha. ${ }^{[6]}$ That's why Garbhini Paricharya has its immense significance in Ayurvedic literature and in current sciences also. As per the theory described in Ayurveda during the process of labor there is aggravation of Vata Dosha out of three Doshas. This is due to obstruction of Garbha and the Nishkramana Kriya of Garbha is effected which is to be performed by Apana Vayu. ${ }^{[7]}$ So to normalise the function of Vata the use of Taila and Madhur Dravyas as Anuvasana Basti and Pichu is done which act as the best Shaman Aushadhi of Vata. ${ }^{[8]}$ As it is mentioned that Acharya Charaka has recommended the use of Anuvaasana Vasti by the side of Yoni Picchu in the $9^{\text {th }}$ month of pregnancy for lubrication of Garbhasthana ${ }^{[5]}$ that is uterus but here cervix and Garbha Marga which symbolize vaginal canal and perineum. Throughout the phase of pregnancy, Vayu Dosha is most likely to be vitiated. To normalise the upset Vayu Dosha Acharya Charaka has mentioned Vasti as Ardha Chikitsa ${ }^{[9]}$ and Vasti is explained as complete Chikitsa to suppress aggravated Vata Dosha by some other Acharyas also.

Vasti is one of the five procedures of Panchakarma, which includes the administration of medicated Kwath Dravyas, oils and fats into the body through anal rout. The Vasti in which Sneha (oils or Ghrita medicated with herbs) is used as main liquid medicine then it is known as Anuvaasana Vasti. Acharya Shushrut has explained it as Snaihika Vasti. ${ }^{[10]}$ Depending on the quantity of Sneha administered Anuvaasana Vasti is divided into three types: Sneha Vasti, Matra Vasti and Anuvaasana Vasti. The Vasti in which the medicines are used in a dose equal to lowest dose of intake of medicated fats or oil it is called Matra Vasti..11] The quantity of medicated
Sneha Dravya is very less and administered in a dose of half of that of Anuvaasana Vasti ( $1 / 2$ of 3 Pala i.e. $1 \frac{1}{2}$ Pala which is approximately 72 grams). ${ }^{[12]}$ It endorse strength, makes the stool and urine to move in proper course, normalise the aggravated Vata Dosha and provide comfort to the body. ${ }^{[13]}$ The Brihattrayi give importance to follow Garbhini Paricharya for the normal and uncomlicated delivery ${ }^{[2]}$ and the role of Apana Vayu in normal labour is also mentioned. ${ }^{[7]}$ Administration of Taila by Anvvaasana Basti helps to reprieve the Rukshata of Vayu by its Snigdha Guna, Laghuta by its Guru Guna, Sheetata of Vayu by its Ushna Guna. ${ }^{[14]}$ With the proper use of Anuvasaana Vasti Vayu moves in right direction i.e. Vatanulomana so the pregnant women delivers easily without any problem. In the current clinical trial to ease down the phenomenon of labor, along with Anuvasaana Vasti Picchu is also used. Picchu a type of oileation treatment or Snehan of a particular localize part of body. Picchu is made up with a cotton swab. Small round cotton swabs were dipped in medicated oil and positioned intensely within the vagina, intact with cervix (yoni) for the Snehana Karma is called as Yoni Picchu. As per the definition of Snehana according to Acharya Charak, it results in Snehana karma (unctuousness), vishyandana (fluidity), mardavata (softness) and kledana (moistness) of body. ${ }^{[15]}$ Anuvaasana Vasti and Yoni Picchu of medicated oil is Vatashamak and grounds the smoothness in channels and tissues which enhance the flexibility of muscles and thus smooth the progress of easy expulsion of the foetus without any obstruction.

Here the clinical trial of an Ayurvedic preparation with main base as Tila Taila is conducted on 30 registered patients. The preparation is named as Sukh-Prasava Taila which is medicated with Madhura Gana Drvayas and four Kwath Dravyas. Sukh-Prasava Taila is given as Anuvasana Basti and Pichhu to the patients from the beginning of $9^{\text {th }}$ month ( 32 weeks) of pregnancy. It maintains the Vata Dosha in Samaya Avastha which is aggravated during labor pains ${ }^{[8]}$ which in the end results in dropping the intensity of labor pain and reduces the duration of all the three stages of labor. 


\section{AIMS AND OBJectives}

1. To study the effect of a Kalpit (self assumed) preparation named as Sukh-Prasava Taila on three stages of labor concerning its stage wise duration and intensity of pain.

2. To study and evaluate its effect on prevalence of caesarean section, forceps application and necessity of episiotomy.

3. To prepare the patient psychologically for comfortable and easy labor.

4. To observe the patient for any problem that takes place after treatment.

\section{Materials And Methods}

\section{Selection of drug}

Acharya Charak mentioned the use of Auvaasana Basti and Yoni Pichu with oil medicated with the drugs of Madhura Gana in the $9^{\text {th }}$ month of pregnancy. ${ }^{[5]}$

\section{Preparation of drug}

The trial drug is prepared in Charak pharmacy of R.G.G.P.G. Ayurvedic College Paprola, under direction of Rasa Shastra Department of the College. In the beginning the Murchhana of Tila Taila is done with the Kalka of Madhur Gana Drvayas ${ }^{[16]}$ as mentioned in table 1. Then Sukh-Prasava Taila is prepared with Taila Paka Vidhi ${ }^{[17]}$ by adding Kwatha of four drugs as mentioned in table 2 .

Table 1: Madhur Gana Dravyas for Murchhana of Sukh-Prasava Taila

\begin{tabular}{|l|l|l|l|}
\hline SN & Drug & Botanical Name & Quantity \\
\hline 1. & Tila Taila & Sesamum indicum & 4 liters \\
\hline 2. & Manjistha & Rubia cordifolia & 250 grams \\
\hline 3. & Amalaki & Emblica officinalis & 60 grams \\
\hline 4. & Vibhitak & Terminalia bellirica & 60 grams \\
\hline 5. & Haritaki & Terminalia chebula & 60 grams \\
\hline 6. & Tvaka & Cinnamomum cassia & 60 grams \\
\hline
\end{tabular}

\begin{tabular}{|l|l|l|l|}
\hline 7. & Ketaki & Pandanus fascicularis & 60 grams \\
\hline 8. & Musta & Cyperus rotundus & 60 grams \\
\hline 9. & Lodhra & Symplocos racemosa & 60 grams \\
\hline 10. & Vata & Ficus benghalensis & 60 grms \\
\hline 11. & Haridra & Curcuma longa & 60 grams \\
\hline 12. & Hriber & Juniperus communis & 60 grams \\
\hline
\end{tabular}

Table 2: Kwatha Dravyas for Sukh-Prasava Taila

\begin{tabular}{|l|l|l|l|}
\hline SN & Drug & Botanical Name & Quantity \\
\hline 1. & Eranda moola & Ricinis communis & 1 part \\
\hline 2. & Ashwagandha moola & Withania somnifera & 1 part \\
\hline 3. & Sariva moola & Hemidesmus indicus & 1 part \\
\hline 4. & Guduchi & Tinospora cordifolia & 1 part \\
\hline 5. & Murchhitta Tila Taila & Sesamum indicum & 16 part \\
\hline
\end{tabular}

Selection of patient

In the present clinical study 30 registered patients were selected who full fills the inclusion criteria and after their consent they were randomly selected from the OPD and IPD of P.G. Deptt. of Prasuti Tantra avum Stree Roga of R.G.G.P.G.Ayu. College and Hospital, Paprola, (H.P)

\section{Inclusion criteria}

1. Pregnant women who were willing for trial and primigravide between 32-36 weeks of pregnancy were randomly selected for the trial with age group between $20-35$ years.

2. Patients having adequate pelvis, border line pelvis and cephalic presentation.

\section{Exclusion criteria}

1. Patient not willing for trial.

2. Age group $<20$ years and $>35$ years.

3. Patients having cephalopelvic disproportion, absolute contracted pelvis, history of APH and Malpresentation. 
4. Patients having systemic disease like diabetes mellitus, hypertension, tuberculosis, jaundice, heart disease, epilepsy, ascitis.

5. Disease related to pregnancy like eclampsia, preeclampsia, polyhydramnios etc.

6. Malignancy of genital tracts.

Plan of study

A detailed research Performa (case history sheet) was prepared to note down all the details of the patients and disease. All the 30 patients were given Anuvaasana Basti and Yoni Pichu as per the following schedule.

Patients were given Anuvaasana Basti (Matra Basti) fortnightly and Yoni Pichu daily till delivery with SukhPrasava Taila.

Anuvaasana Basti (Matra Basti) - $60 \mathrm{ml}$

Yoni Pichu - Soaked with Sukh-Prasava Taila

Parameter for assessment of the Study

Clinically the result was assessed by observing whether the patient had Sukha and Nirupadrava Prasava or not. For this evaluation, following criteria of scoring and criteria for assessment of therapy were adopted;

\section{Onset of labor}

\begin{tabular}{|l|l|}
\hline Onset of labor & Score \\
\hline Spontaneous labor pain & 0 \\
\hline Induced labor pain & 1 \\
\hline
\end{tabular}

2. Intensity of pain during labor

\begin{tabular}{|l|l|}
\hline Intensity of pain during labor & Score \\
\hline Moderate & 0 \\
\hline Mild & 1 \\
\hline Severe & 2 \\
\hline
\end{tabular}

Grading for intensity of pain during labor was done according to the history given by the patients (verbal rating scale).

\section{Pattern of F.H.R.}

\begin{tabular}{|l|l|}
\hline Pattern of F.H.R. & Score \\
\hline FHR between $110-160 / \mathrm{min}$. & 0 \\
\hline Fetal tachycardia $(>160 / \mathrm{min})$. & 1 \\
\hline Fetal bradycardia $(<110 / \mathrm{min})$ & 2 \\
\hline
\end{tabular}

\section{Pattern of Partograph}

\begin{tabular}{|l|l|}
\hline Pattern of Partograph & Score \\
\hline Before alert line & 0 \\
\hline Between alert and action line & 1 \\
\hline On or after action line & 2 \\
\hline
\end{tabular}

\section{Mean Duration of labor}

It is calculated by total time period that is taken for all the three stages labor.

\begin{tabular}{|l|l|}
\hline Mean Duration & Score \\
\hline Less than mean duration & 0 \\
\hline Equal to mean duration & 1 \\
\hline More than mean duration & 2 \\
\hline
\end{tabular}

\section{Type of delivery}

\begin{tabular}{|l|l|}
\hline Type of delivery & Score \\
\hline Normal vaginal delivery without episiotomy & 0 \\
\hline Normal vaginal delivery with episiotomy & 1 \\
\hline Forceps delivery & 2 \\
\hline L.S.C.S. & 3 \\
\hline
\end{tabular}

\section{Postpartum hemorrhage}

\begin{tabular}{|l|l|}
\hline Postpartum hemorrhage & Score \\
\hline No PPH & 0 \\
\hline Third stage PPH & 1 \\
\hline
\end{tabular}


True PPH

Table 3: Gradation Index: On the basis of assessment criteria patients were given following Grades

\begin{tabular}{|l|l|l|l|l|l|}
\hline SN & Criteria & $\begin{array}{l}\text { Grade } \\
\text { I }\end{array}$ & $\begin{array}{l}\text { Grade } \\
\text { II }\end{array}$ & $\begin{array}{l}\text { Grade } \\
\text { III }\end{array}$ & Grade IV \\
\hline 1. & Onset of labor & 0 & 0 & 0 or 1 & 0 or 1 \\
\hline 2. & Intensity of pain & 0 & 0 & 0 or 1 & 1 or 2 \\
\hline 3. & F.H.R. & 0 & 0 & 0 or 1 & 1 or 2 \\
\hline 4. & Partograph & 0 & 0 & 1 & 2 \\
\hline 5. & $\begin{array}{l}\text { Mean duration } \\
\text { of stages }\end{array}$ & 0 & 0 & 1 & 2 \\
\hline 6. & Type of delivery & 0 & 1 & 2 & 3 \\
\hline 7. & $\begin{array}{l}\text { Postpartum } \\
\text { hemorrhage }\end{array}$ & 0 & 0 & 0 or 1 & 0,1 or 2 \\
\hline
\end{tabular}

Grade I (score not $>0$ ): Patients having Spontaneous Normal vaginal delivery with spontaneous onset of labor, moderate uterine contractions, FHR 110$160 /$ min, partograph before alert line, duration of stages less than standard mean duration and no $\mathrm{PPH}$.

Grade II (score not>1): Patients having Normal vaginal delivery with episiotomy, spontaneous onset of labor, moderate uterine contractions, FHR 110-160/min, partograph before alert line, duration of stages less than standard mean duration and no $\mathrm{PPH}$.

Grade III (score not>9): Patients having vaginal delivery assisted with forceps, onset of labor either spontaneous or induced, uterine contractions mild or moderate, FHR $110-160 /$ min or $>160 /$ min or $<110 /$ min., partograph between alert and action line, duration of stages equal to standard mean duration or more with or without PPH.

Grade IV (score not>15): Patients having delivery by LSCS, onset of labor either spontaneous or induced, uterine contractions mild, moderate or severe, FHR $110-160 / \mathrm{min}$ or $>160 / \mathrm{min}$ or $<110 / \mathrm{min}$. partograph on or after action line, duration of stages greater than standard mean duration, with or without $\mathrm{PPH}$.
Criteria for assessment of overall effect of therapy according to gradation index

Grade I - - Marked

Grade II - - Moderate

Grade III _ - Mild

Grade IV $\quad$ - $\quad$ No effect

Laboratory Investigations

- Haematological examination - $\mathrm{Hb}$ gm\%, Blood group with Rh factor, TLC, DLC, ESR, BT, CT, HIV, VDRL, HBsAg, FBS, Lipid profile, LFT, Blood urea, S.Creatinine.

- Urine - Routine and Microscopic examination.

- Ultrasonography

Statistical Analysis

Analysis of data was done on the basis of criteria of assessment and gradation index and interpreted statistically in form of mean score and its comparison with the standard values using student's paired-t test. The student's paired-t test is used to compare the value of significance in the same group (of 30 or less than 30) at two different occasions. Results were considered significant or insignificant depending upon the value of ' $p$ '

Highly significant $\quad \mathrm{p}<0.001$

Significant $\quad p<0.01$;

Significant $\quad p<0.05$

Insignificant $\quad p>0.05$

\section{Observations}

Present study was conducted on 30 registered patients. Out of which 2 patients discontinue before delivery. So, among total 30 patients included in the study, maximum $73.33 \%$ patients belong to age group 20- 25 yrs. 96.66\% patients belong to Hindu community. Maximum 63.33\% patients had education up to higher secondary. $86.66 \%$ were housewives, $60 \%$ patients belongs to middle class. Maximum 50\% patients had constipation. Maximum 60\% patients had normal psychological status. Maximum 70\% were 
vegetarian. 93.33\% patients were having sound sleep. Maximum $66.66 \%$ patients were of Vata-kapha Prakriti. Maximum number of patients i.e. $86.66 \%$ was of Madhayam Samhanana. Maximum $76.66 \%$ of patients were of Madhyam Satva. Maximum 96.66\% of patients had regular past menstrual cycle and normal appetite. Maximum $60 \%$ of patients were registered at 32-34 weeks of gestational period. Maximum $86.66 \%$ of patients had Basti Pratyagamana Kaala of 2 to 4 hours.

\section{RESULTS}

Table 4: Comparison of Standard mean duration of three stages of labor with mean duration of three stages of labor in $\mathbf{2 8}$ patients.

\begin{tabular}{|c|c|c|c|c|c|c|}
\hline $\begin{array}{l}\text { Standar } \\
\text { d labor }\end{array}$ & $\begin{array}{l}\text { Standar } \\
\text { d mean } \\
\text { duration }\end{array}$ & $\begin{array}{l}\text { Mean } \\
\text { duratio } \\
n \quad \text { of } \\
\text { three } \\
\text { stages } \\
\text { of labor } \\
\text { in } 28 \\
\text { patients }\end{array}$ & S.D. & S.E. & $\mathbf{T}$ & $\mathbf{P}$ \\
\hline Stage (I) & $\begin{array}{l}13.3 \\
(13 \mathrm{hr} . \\
8 \mathrm{~min})\end{array}$ & $\begin{array}{l}7.37 \\
(7 \mathrm{hrs} \\
22 \mathrm{~min})\end{array}$ & 1.66 & .320 & $\begin{array}{l}18.4 \\
0\end{array}$ & $\begin{array}{l}<0.00 \\
1\end{array}$ \\
\hline Stage (II) & $\begin{array}{l}0.95 \\
(57 \mathrm{~min})\end{array}$ & $\begin{array}{l}0.43 \\
(25 \mathrm{~min} \\
44 \mathrm{sec} .)\end{array}$ & 8.95 & 1.72 & $\begin{array}{l}18.1 \\
3\end{array}$ & $\begin{array}{l}<0.00 \\
1\end{array}$ \\
\hline $\begin{array}{l}\text { Stage } \\
\text { (III) }\end{array}$ & $\begin{array}{l}0.25 \\
(15 \mathrm{~min})\end{array}$ & $\begin{array}{l}0.06 \\
(3 \mathrm{~min} \\
25 \mathrm{sec} .)\end{array}$ & $\begin{array}{l}0.92 \\
8\end{array}$ & $\begin{array}{l}0.18 \\
9\end{array}$ & $\begin{array}{l}61.1 \\
0\end{array}$ & $\begin{array}{l}<0.00 \\
1\end{array}$ \\
\hline
\end{tabular}

Table 5: Effect of therapy on type of delivery in $\mathbf{2 8}$ patients

\begin{tabular}{|l|l|l|l|}
\hline SN & Type of Delivery & No. of Patients & Percentage \\
\hline 1. & Normal & 15 & $53.57 \%$ \\
\hline 2. & Episiotomy & 11 & $39.29 \%$ \\
\hline 3. & Use of Forcep & 01 & $3.57 \%$ \\
\hline 4. & L.S.C.S. & 01 & $3.57 \%$ \\
\hline
\end{tabular}

Table 6: Effect of therapy on intensity of pain during first and second stage labor in 28 patients

\begin{tabular}{|c|c|c|c|c|}
\hline \multirow[t]{2}{*}{$\begin{array}{l}\text { Intensity } \\
\text { of Pain }\end{array}$} & \multicolumn{2}{|c|}{$\begin{array}{l}\text { During First Stage of } \\
\text { Labor }\end{array}$} & \multicolumn{2}{|c|}{$\begin{array}{l}\text { During Second Stage of } \\
\text { Labor }\end{array}$} \\
\hline & $\mathbf{N}$ & $\%$ & $\mathbf{N}$ & $\%$ \\
\hline Mild & 04 & $14.29 \%$ & 01 & $3.57 \%$ \\
\hline Moderate & 24 & $85.71 \%$ & 26 & $92.85 \%$ \\
\hline Severe & 00 & 00 & 01 & $3.57 \%$ \\
\hline
\end{tabular}

Table 7: Overall Result of therapy in 28 patients

\begin{tabular}{|l|l|l|l|l|}
\hline SN & Result & Effect of therapy & No. of patients & Percentage \\
\hline 1. & $\begin{array}{l}\text { Grade- } \\
\text { I }\end{array}$ & Marked & 15 & $53.57 \%$ \\
\hline 2. & $\begin{array}{l}\text { Grade- } \\
\text { II }\end{array}$ & Moderate & 11 & $39.29 \%$ \\
\hline 3. & $\begin{array}{l}\text { Grade- } \\
\text { III }\end{array}$ & Mild & 01 & $3.57 \%$ \\
\hline 4. & $\begin{array}{l}\text { Grade- } \\
\text { IV }\end{array}$ & No & 01 & $3.57 \%$ \\
\hline
\end{tabular}

Out of 28 patients $53.57 \%$ patients showed marked effect of therapy, $39.29 \%$ patients showed moderate effect of therapy then $3.57 \%$ patients showed mild effect of therapy and $3.57 \%$ patient showed no effect of therapy.

\section{DissCUSSION}

The present clinical trial was done on 30 patients and completed by 28 patients. The medicine used in the trial for Anuvasana Basti and Pichu is Sukh-Prasava Taila. The trial drug was prepared by the Tila Taila as base which is medicated with the Kalka of Dravyas of Madhur Gana and later on the Kawath of four Dravyas is added. The medicine Sukh-Prasava Taila shows significant $(p<0.05)$ results after statistical analysis of assessment criteria but no significant changes were observed in the laboratory investigations. It is the effect of trial drug that all the 
patients had spontaneous nature of labour, maximum with normal and episiotomy mode of delivery and it extremely reduces the standard mean duration of all the three stages of labour which ultimately helps in reducing the intensity of pain and discomfort during the three stages of labor.

At normal term pregnancy the phenomenon of birth is accomplished by a corresponding ripening and dilatation of cervix, go together with the uterine contractions and descent of presenting part. The cervical ripening is the result of rearrangement of collagen, deprivation of collagen cross linking due to proteolytic enzymes. Tila Taila which is the main content of Sukh-Prasava Taila has high percentage of poly-unsaturated fatty acid (omega- 6 fatty acid). Prostaglandins induce pain signals, regulation of inflammation and maintenance of tissue. The role of fatty acid in cervical ripening and parturition has been established. Further local application of Sukh-Prasava Taila in form of Yoni Pichu restores moisture of genital tract. The other constituents of Sukh-Prasava Taila increases the secretion of lysozymes and granular enzymes which increase the collagenolytic activity finally results in cervical ripening. ${ }^{[18]}$ At the other end Anuvaasana and Matrabasti got the property to control sympathetic activity by regulating adrenaline and noradrenaline secretions and helps in maintaining the balance of A.N.S. ${ }^{[19]}$ which regulates myometrium and in the end ultimately helps in labor. ${ }^{[20]}$ The Ferguson reflex is an example of positive feedback and response of female body to pressure application in the cervix or vaginal walls. On application of pressure, oxytocin is released and uterine contractions are stimulated (which will in turn increase oxytocin production, and hence, increase contractions even more) until the baby is delivered. Oxytocin acts on myometrium, on receptors which have been upregulated by an increasing estrogenprogesterone ratio. ${ }^{[21]}$ The administration of Yoni Pichu apply a mild and continuous stretching pressure on the cervix and vaginal wall. So there may be possibility that this pressure may cause the Ferguson reflex in the mild form and consequently help in cervical ripening.

\section{CONCLUSION}

The current study was designed to evaluate the effect of a Kalpit (self assumed) preparation i.e. SukhPrasava Taila on three stages of labor regarding its stage wise duration and intensity of pain. The study reveals that the use of Sukh-Prasava Taila for Anuvasana Vasti and Yoni Pichu decreases the duration of all the three stages of labor significantly and also reduces the intensity of pain during labor.

\section{REFERENCES}

1. Agnivesha. Charaka Smahita, revised by Charaka and Dridhabala, with Ayurveda Dipika commentary of Chakrapanidatta, edited by: Vaidya Jadavaji Trikamji Acharya. Reprint: 2009, Varanasi: Chaukhmba Subharti Prakashan, Sutra Sthan, 6/103-104 p. - 132.

2. Agnivesha. Charaka Smahita, revised by Charaka and Dridhabala, with Ayurveda Dipika commentary of Chakrapanidatta, edited by: Vaidya Jadavaji Trikamji Acharya. Reprint: 2009, Varanasi: Chaukhmba Subharti Prakashan, Sharir Sthan, 8/32 p. - 831.

3. Sushruta. Sushruta samhita. Edited by: Kaviraja Ambikadutta Shastri. $14^{\text {th }}$ edition,Reprint:2003. Varanasi :Chakhamba Sanskrit Sansthan, Nidansthana, 8/78, p.-224.

4. P.V. Tiwari, Ayurvediya Prasutitantra evam Striroga, Vol. 1, Reprint: 2005, Varanasi: Chaukhmba Orientalia, Prasava vigyan, Ch.8, p.- 452.

5. Agnivesha. Charaka Smahita, revised by Charaka and Dridhabala, with Ayurveda Dipika commentary of Chakrapanidatta, edited by: Vaidya Jadavaji Trikamji Acharya. Reprint: 2009, Varanasi: Chaukhmba Subharti Prakashan, Sharir Sthan, 8/40 p.- 833.

6. Agnivesha. Charaka Smahita, revised by Charaka and Dridhabala, with Ayurveda Dipika commentary of Chakrapanidatta, edited by: Vaidya Jadavaji Trikamji Acharya. Reprint: 2009, Varanasi: Chaukhmba Subharti Prakashan, Sharir Sthan, 8/22 p.- 828.

7. Agnivesha. Charaka Smahita, revised by Charaka and Dridhabala, with Ayurveda Dipika commentary of Chakrapanidatta, edited by: Vaidya Jadavaji Trikamji Acharya. Reprint: 2009, Varanasi: Chaukhmba Subharti Prakashan, Chikitsa Sthan, 28/10-11 p. - 778. 
8. Agnivesha. Charaka Smahita, revised by Charaka and Dridhabala, with Ayurveda Dipika commentary of Chakrapanidatta, edited by: Vaidya Jadavaji Trikamji Acharya. Reprint:2009, Varanasi: Chaukhmba Subharti Prakashan, Sutra Sthan, 26/40,41,42. p. - 344.

9. Agnivesha. Charaka Smahita, revised by Charaka and Dridhabala, with Ayurveda Dipika commentary of Chakrapanidatta, edited by: Vaidya Jadavaji Trikamji Acharya. Reprint: 2009, Varanasi: Chaukhmba Subharti Prakashan, Sidhi Sthan, 1/39. p. - 674.

10. Sushruta. Sushruta samhita. Edited by: Kaviraja Ambikadutta Shastri. $14^{\text {th }}$ edition,Reprint:2003. Varanasi :Chakhamba Sanskrit Sansthan, Chikitsasthana, 35/18, p.-354.

11. Agnivesha. Charaka Smahita, revised by Charaka and Dridhabala, with Ayurveda Dipika commentary of Chakrapanidatta, edited by: Vaidya Jadavaji Trikamji Acharya. Reprint: 2009, Varanasi: Chaukhmba Subharti Prakashan, Sidhi Sthan, 4/53. p. - 778.

12. Sushruta. Sushruta samhita. Edited by: Kaviraja Ambikadutta Shastri. $14^{\text {th }}$ edition,Reprint:2003. Varanasi :Chakhamba Sanskrit Sansthan, Chikitsasthana, 35/40, p.-356.

13. Agnivesha. Charaka Smahita, revised by Charaka and Dridhabala, with Ayurveda Dipika commentary of Chakrapanidatta, edited by: Vaidya Jadavaji Trikamji Acharya. Reprint: 2009, Varanasi: Chaukhmba Subharti Prakashan, Sidhi Sthan, 4/53. p. - 726.

14. Agnivesha. Charaka Smahita, revised by Charaka and Dridhabala, with Ayurveda Dipika commentary of Chakrapanidatta, edited by: Vaidya Jadavaji Trikamji Acharya. Reprint:2009, Varanasi: Chaukhmba Subharti Prakashan, Sidhi Sthan, 1/23-30. p. - 673.
15. Agnivesha. Charaka Smahita, revised by Charaka and Dridhabala, with Ayurveda Dipika commentary of Chakrapanidatta, edited by: Vaidya Jadavaji Trikamji Acharya. Reprint:2009, Varanasi: Chaukhmba Subharti Prakashan, Sutra Sthan, 22/11. p.- 284.

16. Proff. Siddhi Nandan Mishra, Bhaishjya Ratnawali, Reprint: 2005, Varanasi: Chaukambha Surbharti Prakashan, Ch. 5/1268.p.-206.

17. Proff. Siddhi Nandan Mishra, Bhaishjya Ratnawali, Reprint: 2005, Varanasi: Chaukambha Surbharti Prakashan, Ch. 5/1264-1265.p.-206.

18. Journal of immunology, abstract Eur. J. Pharmacology, vol. 5, p.34.

19. P.V. Tiwari, Ayurvediya Prasutitantra evam Striroga, Vol. 1, Reprint: 2005, Varanasi: Chaukhmba Orientalia, Prasava vigyan, Ch.8, p.- 452.

20. Dr. M.R. Vasudevan Nam Poothri \& Dr L. Mahadevan, Principles and practice of Basti, Reprint 2009, Varanasi: Chaukambha Surbharti Prakashan, Ch.4,p.114.

21. Martin h. Johnson, Essential of reproduction, $6^{\text {th }}$ edition, Reprint: 2006, New Delhi; Jaypee Brothers Medical Publishers (P) Ltd, Ch.7,p.289.

How to cite this article: Dr. Priyanka. Effect of Ayurvedic preparation on stages of labor - A Clinical Study. J Ayurveda Integr Med Sci 2020;1:37-44. http://dx.doi.org/10.21760/jaims.5.1.8

Source of Support: Nil, Conflict of Interest: None declared.

Copyright (C) 2020 The Author(s); Published by Maharshi Charaka Ayurveda Organization, Vijayapur (Regd). This is an open-access article distributed under the terms of the Creative Commons Attribution License (http://creativecommons.org/licenses/by/4.0), which permits unrestricted use, distribution, and reproduction in any medium, provided the original work is properly cited. 